\title{
Factors affecting the entry of testosterone into the lumen of the cauda epididymidis of the anaesthetized rat
}

\author{
T. G. Cooper and G. M. H. Waites \\ Department of Physiology \& Biochemistry, The University, Whiteknights, Reading RG6 2AJ, \\ Berkshire, U.K.
}

\begin{abstract}
Summary. When $\left[{ }^{3} \mathrm{H}\right]$ testosterone was infused into the general circulation of the rat, perfusion of a length of the cauda epididymidis $(17 \pm 1.0$ (s.e.m.) $\mathrm{cm}, n=36$ ) with perfusates of varied composition revealed a low entry of radioactivity $(1-10 \%$ plasma levels; 10 exps) with protein-free perfusates, and a greater entry $(15-48 \% ; 10$ exps) when the perfusate contained bovine serum albumin $(38 \mathrm{mg} / \mathrm{ml})$. When the perfusate contained ovine or rat testicular fluid, or rat epididymal fluid at protein concentrations of $3 \mathrm{mg} / \mathrm{ml}$ or less, the entry of radioactivity into the epididy mis was greater than when the perfusate contained $3 \mathrm{mg} \mathrm{BSA} / \mathrm{ml}$. The addition of ovine rete testis fluid protein $(3 \mathrm{mg} / \mathrm{ml})$ to BSA $(38 \mathrm{mg} / \mathrm{ml})$ in the perfusate increased the uptake of radioactivity (58-106\%; 6 exps).

Radioactivity in blood was principally associated with testosterone (90, 95\% total blood activity, 2 rats), whereas both $\left[{ }^{3} \mathrm{H}\right]$ testosterone $(37,41 \%$ total perfusate activity) and $\left[{ }^{3} \mathrm{H}\right]$ dihydrotestosterone $(42,63 \%$ total perfusate activity) were present in BSA-containing perfusates. The proportion of dihydrotestosterone appeared to in crease when the perfusate contained protein of testicular origin.
\end{abstract}

\section{Introduction}

The importance of androgens for maturation and storage of spermatozoa in the epididymis has been emphasized (Orgebin-Crist, Danzo \& Davies, 1975). Androgen action is believed to be indirect, mediated by receptors in the epididymis (Hansson, Ritzen \& French, 1975). A direct action of steroids on spermatozoa cannot be ruled out, however, because a variety of free steroids have been found in the fluid in the cauda epididymidis of the conscious bull (Ganjam \& Amann, 1976) and ram (Voglmayr et al., 1977). Nevertheless, direct evidence for effects of steroids on the metabolism of epididymal spermatozoa from these species has only been achieved with higher concentrations than are normally present (Voglmayr, 1975; Hammerstedt \& Amann, 1976).

The epididymis receives steroids in rete testis fluid (Waites, 1977), indirectly from the circulation, and by epididymal synthesis (Hamilton, 1971). The present study was done to examine the entry of testosterone from the circulation into the epididymal lumen when perfused with solutions of varied protein composition.

\section{Materials and Methods}

\section{Surgical procedure}

Male CD rats (Charles River, U.K. Ltd, Manston, Kent), 314-570 g, were fed diet 86 (Dixon \& Sons (Ware) Ltd, U.K.) and water ad libitum. They were anaesthetized with sodium pentobarbitone (Sagatal: May \& Baker, Dagenham; $60 \mathrm{mg} / \mathrm{kg}$; i.p.) and after insertion of a tracheal cannula the common carotid artery, external jugular vein, and each vas deferens and 
cauda epididymidis were cannulated as previously described (Cooper \& Waites, 1979) except that polytetrafluoroethylene (PTFE, Teflon) catheters were inserted into the jugular vein $(0.5 \mathrm{~mm}$ i.d., $0.9 \mathrm{~mm}$ o.d.: Vactite Ltd, Bootle, Lancs.) and attached to the needle in the vas deferens $(0.3$ $\mathrm{mm}$ i.d., $0.5 \mathrm{~mm}$ o.d.: Croylek Ltd, Coulsdon, Surrey). The luminal contents were removed by an initial perfusion at $8 \mu \mathrm{l} / \mathrm{min}$ for $10 \mathrm{~min}$. During the infusions the perfusion rate was varied from $3.9-15.4 \mu \mathrm{l} / \mathrm{min}$ ('high' perfusion rates) to $1.2-2.6 \mu \mathrm{l} / \mathrm{min}$ ('low' perfusion rates) to determine any perfusion rate dependence. The length of the perfused segment was obtained at the end of the experiment from a latex cast (Gerrard \& Co. Ltd, Sussex) measured after digestion of the tissue with $2 \mathrm{M}-\mathrm{KOH}$.

\section{Perfusion fluids}

The perfusion fluid was isosmotic with epididymal plasma $(336 \mathrm{mosmol} / \mathrm{kg}$ : Levine \& Marsh, 1971 ) and was composed of unbuffered $168 \mathrm{~mm}$-sodium chloride (3 rats) or $50 \mathrm{mm-morpholino-}$ propanesulphonic acid (MOPS), $\mathrm{pH}$ 6.85, made 336 mosmol with sodium chloride. Bovine serum albumin was Cohn Fraction V (Sigma). Ovine rete testis fluid (oRTF) was obtained as described by Edwards, Dacheux \& Waites (1976) and generously donated by Dr J. S. Walton. Sperm-free oRTF (100 ml) was freeze dried, taken up in $10 \mathrm{ml}$ water and dialysed against distilled water for $48 \mathrm{~h}$ at $4^{\circ} \mathrm{C}$. The non-dialysable portion was freeze-dried; it liquefied forming a brown solution, when warmed to room temperature. The protein concentration was $120 \mathrm{mg} / \mathrm{ml}$ and it was stored at $-20^{\circ} \mathrm{C}$. Rete testis fluid was collected from two rats by the method of Tuck, Setchell, Waites \& Young (1970). It was separated from spermatozoa by centrifugation at $1500 \mathrm{~g}$ for $15 \mathrm{~min}$ and stored at $4^{\circ} \mathrm{C}$. Epididymal plasma was obtained by diluting 25 -fold in $154 \mathrm{~mm}$-sodium chloride the contents of the cauda epididymidis of 1 rat before luminal perfusion. The supernatant was used after centrifugation. This diluent was chosen because it is isosmotic with rete testis fluid (Johnson \& Howards, 1976) which was perfused through the lumen of the contralateral epididymis.

Perfusates containing bovine serum albumin (BSA), oRTF and the effluent from protein-free perfusates were checked for enzymic activity by incubating duplicate aliquots with $\left[{ }^{3} \mathrm{H}\right]$ testosterone for $2 \mathrm{~h}$ at $33^{\circ} \mathrm{C}$. Ether-extractable metabolites were separated by thin-layer chromatography.

\section{Infusion solutions}

$\left[1,2,6,7-{ }^{3} \mathrm{H}\right]$ Testosterone (sp. act. 80-93 Ci/mmol; Radiochemical Centre, Amersham, Bucks, U.K.) was dissolved in $1 \%$ ethanol in $154 \mathrm{~mm}$-sodium chloride and infused into the jugular vein at a mean rate of $0.7 \mu \mathrm{Ci} / \mathrm{min}(1.0 \mathrm{ml} / \mathrm{h})$ for $60-90 \mathrm{~min}$. Two rats were infused with $3 \mu \mathrm{Ci} / \mathrm{min}$ for $120 \mathrm{~min}$ for radiometabolite analysis by thin-layer chromatography (1 rat) or gasliquid chromatography (1 rat).

\section{Experimental protocol}

Consecutive 10 -min collections of perfusate were stored on ice throughout the experiment and the blood level of radioactivity was monitored by sampling from the carotid cannula midway through each collection of perfusate. Radioactivity in the samples of perfusate $(10 \mu \mathrm{l})$ and plasma $(20 \mu \mathrm{l})$ was estimated by liquid scintillation spectrophotometry on a Packard Tricarb 3255 as described by Cooper \& Waites (1979).

\section{Steroid analyses}

Free steroids were extracted from plasma and pooled perfusates with 15 volumes of freshly distilled diethyl ether. After removal of the organic phase, conjugated steroids were extracted (McKenna \& Rippon, 1965). Steroid acetates were made by incubation for $1 \mathrm{~h}$ at $60^{\circ} \mathrm{C}$ with pyridine : acetic anhydride $(1: 1, \mathrm{v} / \mathrm{v})$. 
Thin-layer chromatography. This was carried out on $250 \mu \mathrm{m}$ thick silica gel ('silica': SilicAR TLC7GF, Mallinckrodt) or neutral aluminium oxide ('alumina': type T, Merck), activated at $110^{\circ} \mathrm{C}$ for $1 \mathrm{~h}$. Plates were washed in chloroform before use. The solvent systems used for free steroids were (by vol.): (1) chloroform :diethyl ether $(9: 1)$, silica; (2) benzene : ethanol $(97: 3)$, alumina; (3) chloroform :ethanol (99:1), silica; (4) cyclohexane :ethyl acetate (9:1), alumina; (5) chloroform:methanol $(98: 2)$, silica. Conjugated steroids were separated in (6) ethyl acetate : ethanol:ammonia $(5: 5: 1)$, alumina. The plates were developed for $15 \mathrm{~cm}$ in saturated tanks and steroids were visualized with iodine vapour or short u.v. light.

Gas-liquid chromatography. This was carried out on a Series 104 gas chromatograph (Pye Unicam, Cambridge, U.K.) interphased with an effluent gas monitor system (Panax Instruments, Redhill, Surrey) in which the effluent gas was split, part going to the flame ionisation detector, the rest over furnace tubes containing, sequentially, copper oxide and iron filings, heated to 650 and $600^{\circ} \mathrm{C}$ respectively. The split ratio was $3 \cdot 1-3 \cdot 3$ in favour of the radiodetector. The separating column was $2 \cdot 1 \mathrm{~m} \times 4 \mathrm{~mm}$ glass containing $3 \% \mathrm{QF}-1$ on Chromosorb W.HP (100-120 mesh). A temperature programme of $5 \mathrm{~min}$ at $190^{\circ} \mathrm{C}$ followed by a $1{ }^{\circ} \mathrm{C} / \mathrm{min}$ rise to $240^{\circ} \mathrm{C}$ adequately separated the carrier steroids.

Analytical procedure. For analysis by t.l.c. authentic steroids $(20 \mu \mathrm{g})$ were added to the extract of free steroids and separated on system 1 . The steroids added were testosterone (5-

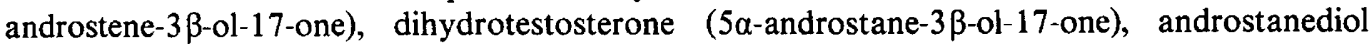
( $5 \alpha$-androstane-3 $\beta, 17 \beta$-diol), androstenedione (5-androstene-3,17-dione) and androstanedione ( $5 \alpha$-androstane-3,17-dione). The plates were scanned for radioactivity (Panax Instruments, Redhill, Surrey) and peaks of activity were scraped from the plate, eluted with diethyl ether and the extracts were rechromatographed on other systems directly or after derivative formation. Estimates of the percentages of the various metabolites were obtained by triangulation of the radiotraces. Conjugated steroids were separated in system 6 after addition of testosterone glucuronide and dehydroepiandrosterone (5-androstene-3 $\beta$-ol-17-one) sulphate, but were not further analysed.

For analysis by g.l.c., $20 \mu \mathrm{g}$ steroid were added to the aliquots of the extracts before injection. The steroids added were testosterone, dihydrotestosterone, androstanediols ( $3 \alpha$ - and

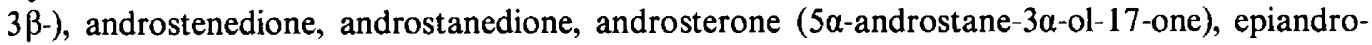
sterone ( $5 \alpha$-androstane-3 $\beta$-ol-17-one) and dehydroepiandrosterone.

\section{Statistical analyses}

These were made with Student's $t$ test.

\section{Results}

The mean \pm s.e.m. length of the perfused tubule was $17.2 \pm 1.0 \mathrm{~cm}$ (range $5.5-35.0 \mathrm{~cm}$; $n=36$ ). The tubules perfused at the slower rate were significantly shorter than those perfused at the high rate (Table 2).

\section{Dynamics of entry of radioactivity}

In one rat each epididymis was perfused in turn with or without bovine serum albumin (38 $\mathrm{mg} / \mathrm{ml}$; Text-fig. 1) at rates of $5 \cdot 2-7 \cdot 5 \mu \mathrm{l} / \mathrm{min}$ during the intravenous infusion of $\left[{ }^{3} \mathrm{H}\right]-$ testosterone. The concentration of radioactivity in the lumen was low on each side when the perfusate was protein-free $(9.3$ and $13.3 \%$ plasma levels), but higher when protein was present ( 34.2 and $41.0 \%$ ), despite differences in the lengths of the perfused tubules on either side (16 and $21 \mathrm{~cm}$; Text-fig. 1). 


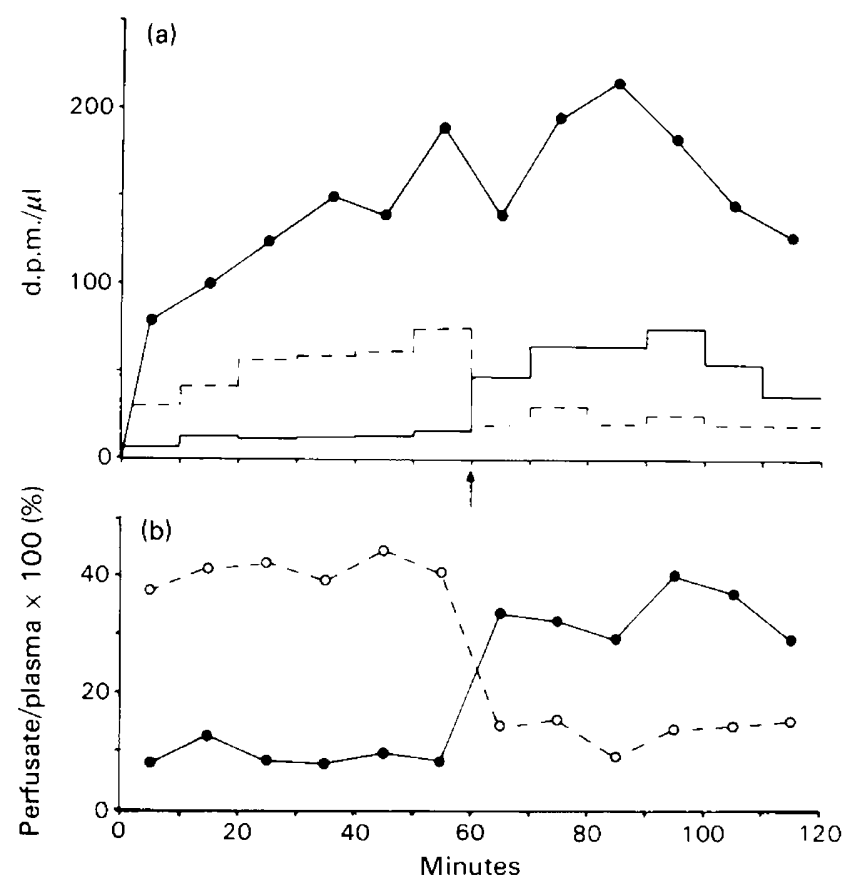

Text-fig. 1. The entry of radioactivity into the lumen of the cauda epididymidis of a rat during intravenous infusion of $\left[{ }^{3} \mathrm{H}\right]$ testosterone. (a) The radioactivity in blood plasma (O) and consecutive 10-min samples of perfusate was measured. The left epididymis (-- - ) was perfused initially with a solution containing bovine serum albumin $(38 \mathrm{mg} / \mathrm{ml})$ and the right ( $\longrightarrow$ ) with a protein-free solution during the period 0-60 $\mathrm{min}$; at $60 \mathrm{~min}$ (arrow) the perfusates were exchanged. (b) The ratios of the radioactivity in the perfusate to that in plasma taken midway through its collection are shown (----, left epididymis; $-\ldots$, right epididymis).

\section{Protein-free perfusates}

At high perfusion rates radioactivity appeared in the luminal perfusate within $10 \mathrm{~min}$ and reached a maximum of $10 \%$ of plasma levels during the infusion $(1-3 \%, 2$ experiments with unbuffered perfusate; $4-10 \%, 3$ experiments with buffered perfusate; Text-fig. 2; Table 2). A similar low entry was observed (5-9\%, 5 exps) at low perfusion rates. When blood levels of radioactivity were decreasing after the end of the infusion, a relative rise in the luminal radioactivity was observed (Text-fig. 2$)$ and it was significantly greater $(P<0.005)$ at the end of the perfusion $(120 \mathrm{~min})$ than at the end of the infusion $(80 \mathrm{~min})$.

\section{Albumin-containing perfusates}

Bovine serum albumin in the perfusates at low concentration $(3 \mathrm{mg} / \mathrm{ml}$; Table 1) marginally increased the entry of radioactivity over that detected in protein-free perfusates (Table 2). The radioactivity present was much greater when the perfusate contained concentrations of protein normally found in epididymal fluid $(38 \mathrm{mg} / \mathrm{ml})$. At the high rate of perfusion the entry of radioactivity was greater when the protein was dissolved in buffered (34-48\%, 4 exps) than in unbuffered $(15 \%, 1$ exp.) perfusate. A similar entry was found at the low perfusion rate (3346\%, 5 exps, Table 2; Text-fig. 2).

\section{Influence of proteins of testicular origin}

When protein from ovine rete testis fluid was perfused through the cauda epididymidis at a low concentration $(120 \mu \mathrm{g} / \mathrm{ml})$ more radioactivity appeared in the perfusate than in protein-free perfusates, the levels being similar to those which accumulated in the presence of a 25 -fold higher 


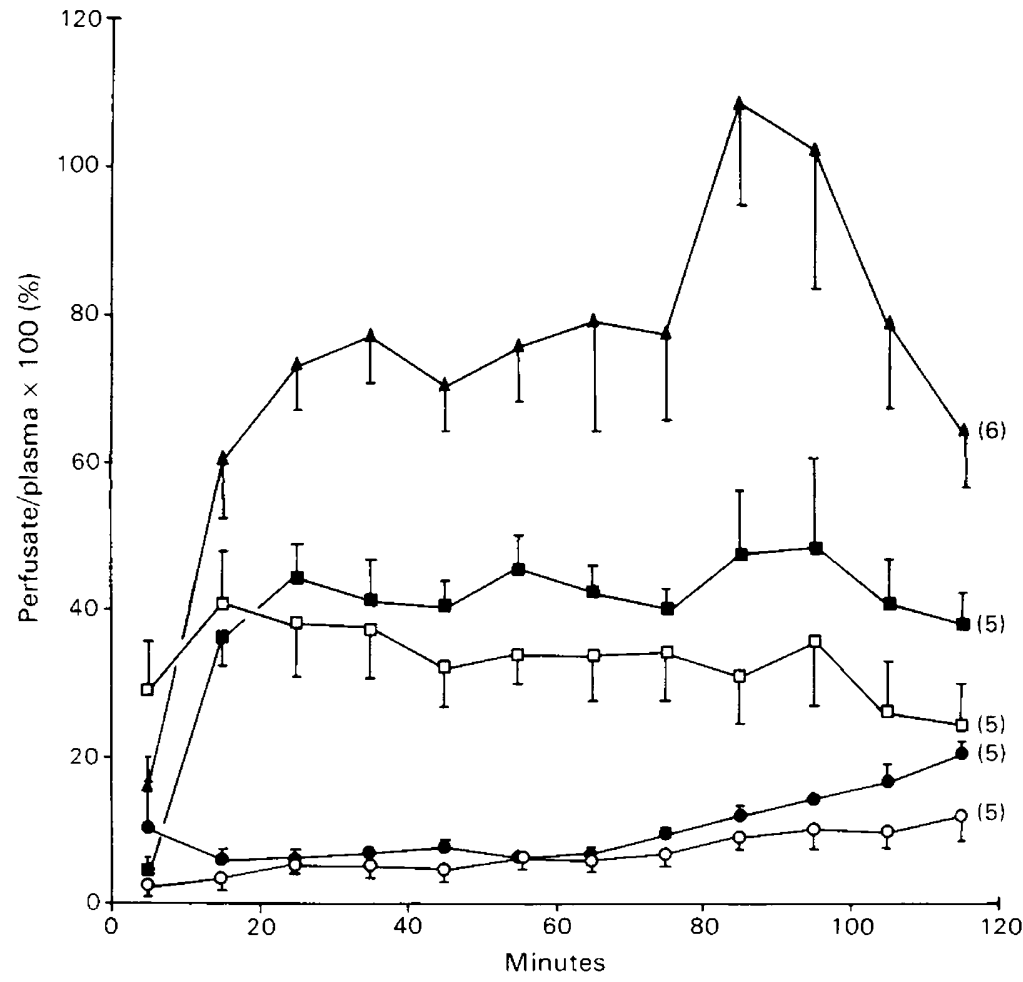

Text-fig. 2. The influence of different proteins in the lumen of the cauda epididymidis on the transfer of radioactivity from blood plasma during the intravenous infusion of $\left[{ }^{3} \mathrm{H}\right]$ testosterone into rats (no. of epididymides in parentheses). The ratio of the concentration of radioactivity in the perfusate to that in blood plasma was calculated at 10 -min intervals during and after infusions lasting $80 \mathrm{~min}$. Perfusates contained no protein $(0,0)$; BSA $(38 \mathrm{mg} / \mathrm{ml}: \square \square)$; or BSA + ovine rete testis fluid $(41 \mathrm{mg} / \mathrm{ml}: \Delta)$. Perfusion rates (see text) were 'high' (open symbols) or 'low' (closed symbols).

concentration of albumin (Table 1). When the concentration of testicular protein was $3 \mathrm{mg} / \mathrm{ml}$, the uptake of radioactivity was 2- to 4-fold greater than during the perfusion of the same concentration of albumin, regardless of the perfusion rate (Table 1). At low perfusion rates, ovine rete testis fluid protein $(3 \mathrm{mg} / \mathrm{ml})$ dissolved in albumin solution $(38 \mathrm{mg} / \mathrm{ml})$ further increased the uptake of tracer (58-106\%, 6 exps, Table 2). Undiluted rat rete testis fluid and diluted rat epididymal fluid both increased the entry of radioactivity into the lumen to greater extents than did higher concentrations of albumin (Table 1).

\section{Effect of perfusion rate and length of perfused tubule}

The entry of tracer was little influenced by either of these factors, although the association of longer perfused segments with higher perfusion rates precludes a definitive statement.

\section{Analysis of ${ }^{3} \mathrm{H}$-steroids in epididymal perfusate and blood}

During the infusion of $\left[{ }^{3} \mathrm{H}\right]$ testosterone, blood plasma contained one peak of activity which migrated with testosterone on the t.l.c. and g.l.c. systems, and comprised 90 and $95 \%$ total plasma activity respectively. Small amounts of androstenedione were detected in one rat (t.l.c. systems 1 and 5, Text-fig. 3) and of dihydrotestosterone in the other (g.l.c., Text-fig. 4). 
Table 1. The effect of quality of protein on the entry of radioactivity into the lumen of the perfused rat cauda epididymidis during intravenous infusion of $\left[{ }^{3} \mathrm{H}\right]$ testosterone*

\begin{tabular}{|c|c|c|c|c|c|}
\hline $\begin{array}{l}\text { Perfusate } \\
\text { protein }\end{array}$ & $\begin{array}{l}\text { Rat } \\
\text { no. }\end{array}$ & $\begin{array}{l}\text { Protein } \\
\text { conc. } \\
(\mathrm{mg} / \mathrm{ml})\end{array}$ & Entry of tracert & $\begin{array}{l}\text { Perfusion } \\
\text { rate } \\
(\mu \mathrm{l} / \mathrm{min})\end{array}$ & $\begin{array}{l}\text { Perfused } \\
\text { length } \\
(\mathrm{cm})\end{array}$ \\
\hline $\begin{array}{l}\text { Bovine } \\
\text { serum } \\
\text { albumin }\end{array}$ & $\begin{array}{l}1 \\
2 \\
3\end{array}$ & $\begin{array}{l}3.0 \\
3.0 \\
3.0\end{array}$ & $\begin{array}{r}8.2 \pm 1.1(5)^{b} \\
9.0 \pm 1.1(5)^{c} \\
13.5 \pm 0.4(6)^{d}\end{array}$ & $\begin{array}{l}6 \cdot 7 \\
1 \cdot 7 \\
2 \cdot 3\end{array}$ & $\begin{array}{l}18 \cdot 0 \\
16 \cdot 0 \\
29 \cdot 0\end{array}$ \\
\hline $\begin{array}{l}\text { Ovine } \\
\text { rete testis } \\
\text { fluid }\end{array}$ & $\begin{array}{l}4 \\
1 \\
2 \\
3\end{array}$ & $\begin{array}{l}0 \cdot 12 \\
3 \cdot 0 \\
3 \cdot 0 \\
3 \cdot 0\end{array}$ & $\begin{array}{r}8.9 \pm 0.5(8)^{\mathrm{a}} \\
17.8 \pm 1.4(5)^{\mathrm{b}} \\
38.1 \pm 1.0(5)^{\mathrm{c}} \\
36.2 \pm 2.1(6)^{\mathrm{d}}\end{array}$ & $\begin{array}{l}6 \cdot 3 \\
7 \cdot 8 \\
2 \cdot 5 \\
2 \cdot 3\end{array}$ & $\begin{array}{l}16 \cdot 5 \\
22 \cdot 0 \\
18 \cdot 5 \\
12 \cdot 0\end{array}$ \\
\hline $\begin{array}{l}\text { Rat } \\
\text { rete testis } \\
\text { fluid }\end{array}$ & 5 & $2 \cdot 6$ & $55.4 \pm 1.6(7)^{e}$ & $2 \cdot 2$ & $11 \cdot 5$ \\
\hline $\begin{array}{l}\text { Rat } \\
\text { epididymal } \\
\text { fluid }\end{array}$ & 5 & 1.4 & $15.5 \pm 1.6(7)^{e}$ & $1 \cdot 3$ & $21 \cdot 0$ \\
\hline
\end{tabular}

* During intravenous infusion of $\left[{ }^{3} \mathrm{H}\right]$ testosterone each cauda epididymidis was perfused with a solution containing (i) ovine rete testis fluid or the same concentration of bovine serum albumin (Rats $1-4$ ) or (ii) undiluted rat rete testis fluid or diluted rat epididymal fluid ( $R$ at 5 ). The radioactivity in the perfusate was calculated as a percentage of that in plasma after equilibration and during the infusion as a measure of entry of tracer. For each rat a mean value from 5-8 sequential samples was obtained.

† Perfusate (d.p.m./ $/ \mu \mathrm{l}) /$ plasma (d.p.m. $/ \mu \mathrm{l}) \times 100(\%)$; values are mean \pm s.e.m. for no. of observations indicated in parentheses.

a, e Significantly different from no protein (Table 2 , line 1 ); ${ }^{\text {a } P}<0.05,{ }^{\mathrm{e}} P<0.005$.

b, c, d Significantly different from group bearing same superscript letter, $P<0.005$.

Table 2. The effect of quantity of protein and perfusion rate on the entry of radioactivity into the lumen of the perfused rat cauda epididymidis during intravenous infusion of $\left[{ }^{3} \mathrm{H}\right]$ testosterone*

\begin{tabular}{|c|c|c|c|c|c|c|}
\hline \multirow[b]{2}{*}{ Perfusate } & \multirow{2}{*}{$\begin{array}{l}\text { No. of } \\
\text { exps }\end{array}$} & \multirow{2}{*}{$\begin{array}{l}\text { Entry of tracer } \dagger \\
(\text { mean } \pm \text { s.e.m.) }\end{array}$} & \multicolumn{2}{|c|}{$\begin{array}{l}\text { Perfusion } \\
\text { rate }(\mu \mathrm{l} / \mathrm{min})\end{array}$} & \multicolumn{2}{|c|}{ Perfused length $(\mathrm{cm})$} \\
\hline & & & Mean & Range & Mean \pm s.e.m. & Range \\
\hline No protein & $\begin{array}{l}5 \\
5\end{array}$ & $\begin{array}{l}5.5 \pm 1 \cdot 8^{\mathrm{a}, \mathrm{b}} \\
7 \cdot 2 \pm 0 \cdot 7^{\mathrm{a}, \mathrm{d}}\end{array}$ & $\begin{array}{l}7 \cdot 3 \\
2 \cdot 3\end{array}$ & $\begin{array}{l}3.9-10 \cdot 3 \\
1.9-2.6\end{array}$ & $\begin{array}{l}21 \cdot 6 \pm 3 \cdot 8^{\mathrm{r}, \mathrm{g}} \\
12 \cdot 2 \pm 1 \cdot 8^{\mathrm{f}, \mathrm{h}}\end{array}$ & $\begin{array}{r}11 \cdot 5-35 \cdot 0 \\
5 \cdot 5-16 \cdot 5\end{array}$ \\
\hline BSA & $\begin{array}{l}5 \\
5\end{array}$ & $\begin{array}{l}35 \cdot 2 \pm 5 \cdot 7^{\mathrm{b}, \mathrm{c}} \\
41 \cdot 4 \pm 2 \cdot 5^{\mathrm{c}, \mathrm{d}, \mathrm{e}}\end{array}$ & $\begin{array}{l}9.4 \\
1.8\end{array}$ & $\begin{array}{l}5 \cdot 2-15 \cdot 4 \\
1 \cdot 6-2 \cdot 2\end{array}$ & $\begin{array}{l}21 \cdot 5 \pm 1 \cdot 1^{\mathrm{g}, \mathrm{e}} \\
15 \cdot 3 \pm 1 \cdot 7^{\mathrm{h}, \mathrm{e}, \mathrm{J}}\end{array}$ & $\begin{array}{r}18 \cdot 0-25 \cdot 0 \\
5 \cdot 5-20 \cdot 0\end{array}$ \\
\hline oRTF + BSA & 6 & $63 \cdot 7 \pm 19 \cdot 7^{\mathrm{e}}$ & 1.9 & $1 \cdot 2-2 \cdot 3$ & $15 \cdot 9 \pm 1.0^{\mathrm{J}}$ & $12 \cdot 0-18 \cdot 0$ \\
\hline
\end{tabular}

Values with the same superscript letter are significantly different: ${ }^{\mathrm{b}, \mathrm{d}} P<0.005,{ }^{1} P<0.01,{ }^{\mathrm{e}} P<0.025,{ }^{\mathrm{f}} P<0.05$.

* During intravenous infusion of $\left[{ }^{3} \mathrm{H}\right]$ testosterone each cauda epididymidis was perfused with a solution containing (i) no protein, (ii) bovine serum albumin $(38 \mathrm{mg} / \mathrm{ml}$ ), or (iii) ovine rete testis fluid protein $(3 \mathrm{mg} / \mathrm{ml}$ ) and bovine serum albumin $(38 \mathrm{mg} / \mathrm{ml})$. The radioactivity in the perfusate was calculated as a percentage of that in plasma after equilibration and during infusion as a measure of entry of tracer. For each rat a mean value from 5-8 sequential samples was obtained.

$\uparrow$ Perfusate (d.p.m. $/ \mu \mathrm{l}) /$ plasma (d.p.m. $/ \mu \mathrm{l}) \times 100(\%)$.

The epididymal perfusates contained two major peaks of radioactivity which migrated with testosterone and dihydrotesterone in t.l.c. systems 1 and 2 and their acetates in systems 1 and 4, as well as on g.l.c. The percentage activity associated with testosterone was $41 \%$ (rat 1 , t.l.c.) and $37 \%$ (rat 2, g.l.c.), and with dihydrotestosterone was $42 \%$ (rat 1, t.l.c.) and $63 \%$ (rat 2, g.l.c.). Little polar material was present; there was evidence for the presence of androstenedione 
in one rat (t.l.c. system 1, Text-fig. 3) and androstenediols in the other (g.l.c., Text-fig. 4). There was relatively less testosterone (28 and $23 \%$, rats 1 and 2 , respectively) and more dihydrotestosterone (51 and 68\%, rats 1 and 2 , respectively) in perfusates containing ovine rete testis fluid protein (Text-figs 3 and 4). Neither protein-containing perfusate nor the effluent of the protein-free perfusate metabolized $\left[{ }^{3} \mathrm{H}\right]$ testosterone in vitro.

No conjugated steroids were detected in the epididymal perfusates, although some radioactive material in blood plasma remained close to the origin in t.l.c. system 6 .

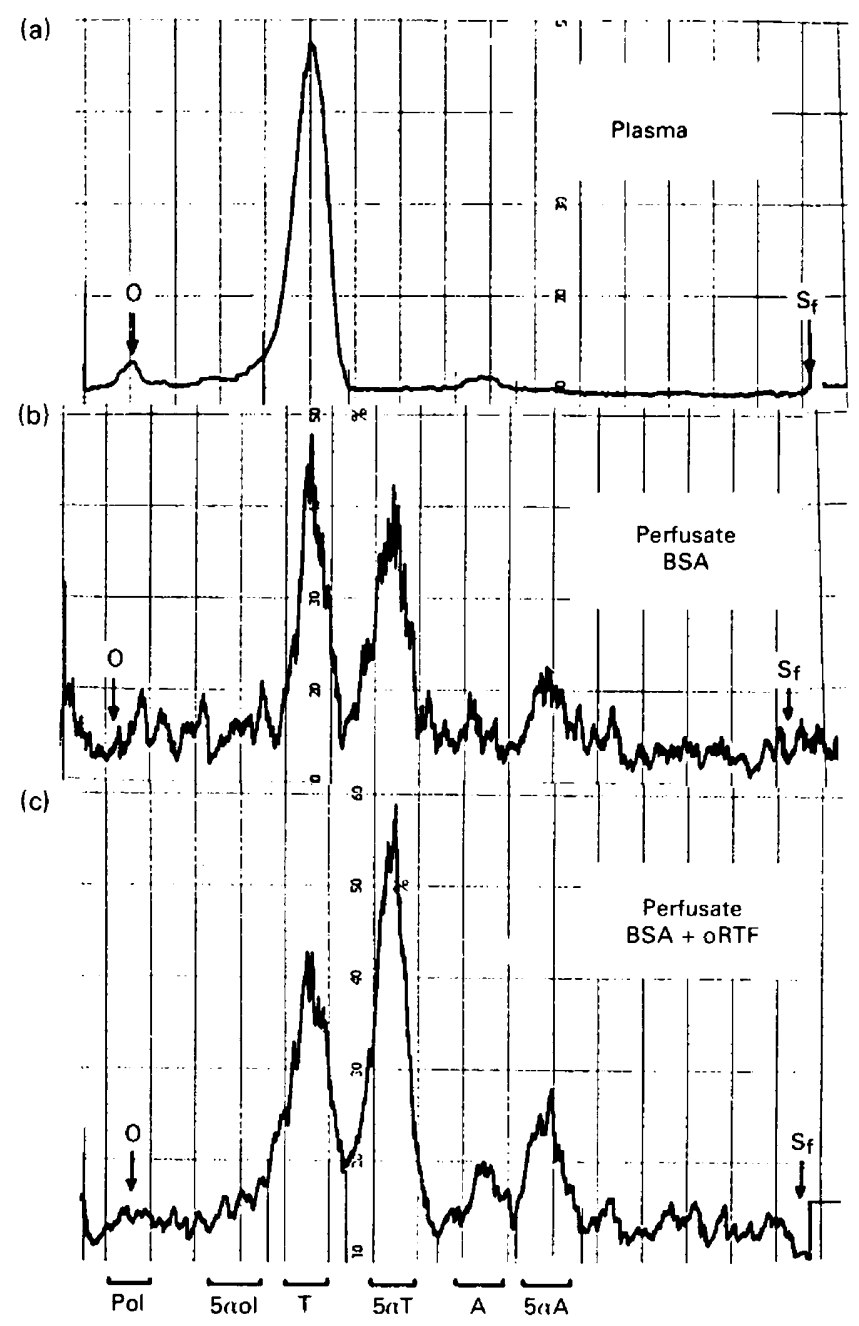

Text-fig. 3. Analysis of radiometabolites by t.l.c. during the intravenous infusion of $\left[{ }^{3} \mathrm{H}\right]$ testosterone into one rat. Radiodetector traces of ether-extractable radioactivity developed on silica in chloroform : diethyl ether $(90: 10, \mathrm{v} / \mathrm{v})$ from origin $(\mathrm{O})$ for $15 \mathrm{~cm}$ (solvent front, $\mathrm{S}_{\mathrm{f}}$ ). Most plasma activity (a) migrated with testosterone ( $T$ ), but radioactivity in the protein-containing perfusates (b, BSA, c, BSA + ovine rete testis fluid) migrated with testosterone and dihydrotestosterone ( $5 \alpha-\mathrm{T})$. There is a suggestion of some activity migrating with androstanedione (5aA). Other steroids are: polar steroids (Pol), androstanediols (5a-ol), and androstenedione (A). 
(a) Plasma

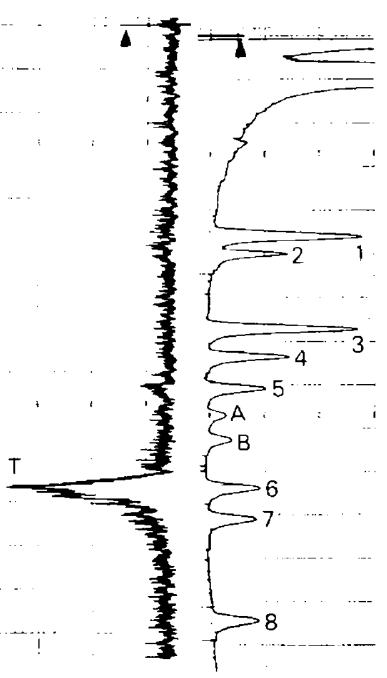

(b) Perfusate BSA

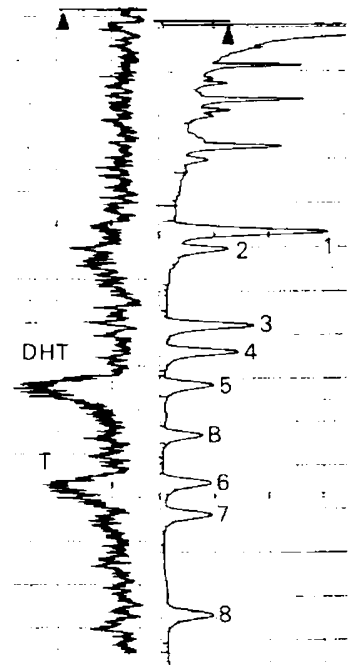

(c) Perfusate BSA + oRTF

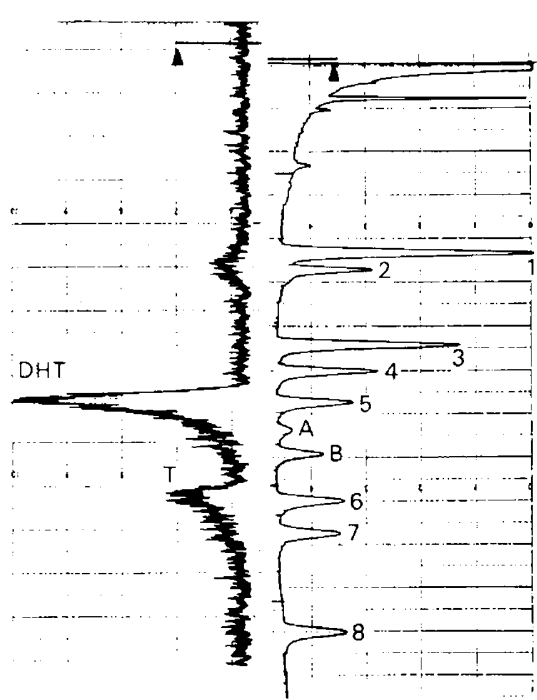

Text-fig. 4. Analysis of radiometabolites in (a) plasma, (b), perfusate containing BSA ( 38 $\mathrm{mg} / \mathrm{ml}$ ) and (c) perfusate containing BSA + ovine rete testis fluid $(41 \mathrm{mg} / \mathrm{ml})$ by g.l.c. during intravenous infusion of $\left[{ }^{3} \mathrm{H}\right]$ testosterone into one rat. In each panel the smooth trace to the right is the mass response; the jagged trace to the left that of the radiodetector. Because of the time-lag between steroids passing through the flame ionisation and radiodetectors, mass and radio-traces for each steroid are normally out of alignment. The traces are here aligned; the extent of their displacement is revealed by the distance between the injection points (horizontal lines with arrowheads, top of each panel). $\left[{ }^{3} \mathrm{H}\right]$ Testosterone was the major circulating steroid and both $\left[{ }^{3} \mathrm{H}\right]$ testosterone and $\left[{ }^{3} \mathrm{H}\right]$ dihydrotestosterone were present in the protein-containing perfusates. There was a suggestion of some radioactivity migrating with androstanediols. Steroids added were: androstanediol-3 $\alpha$ and androstenediol (Peak 1), androstanediol-3 $\beta$ (Peak 2), androsterone and dehydroepiandrosterone (Peak 3), epiandrosterone (Peak 4), dihydrotestosterone (Peak 5), testosterone (Peak 6), androstanedione (Peak 7), androstenedione (Peak 8). Peaks A and B originated from the sample.

\section{Discussion}

Free steroids can pass from the blood to the epididymal lumen of the perfused cauda epididymidis. The rate of appearance of radioactivity during infusions of $\left[{ }^{3} \mathrm{H}\right]$ testosterone was rapid (within $10 \mathrm{~min}$ ) but the extent of entry was determined by the composition of the perfusate, particularly the presence and nature of protein. When blood levels of radioactivity were falling at the end of the infusion, protein-free perfusates continued to accumulate radioactivity, which suggests that the activity originated from some source other than blood, e.g. epididymal tissue. In contrast, in the presence of luminal binding proteins there was a greater, but transient, increase in radioactivity, reflecting its retention within the lumen, followed by its migration out of the lumen with the perfusate, rather than through the walls of the organ.

Albumin, a non-specific steroid-binding protein (Westphal, 1975), significantly increased the entry of testosterone from blood compared with protein-free perfusates. This presumably reflects the greater solubility of the steroid in protein solution (Bischoff \& Stauffer, 1954; Eik-Nes, Schellman, Lumry \& Samuels, 1954), and in this study the concentration of protein in the perfusate was that normally present in epididymal fluid (Back \& Shenton, 1975). The significance of plasma proteins, especially albumin, in the secretion of steroids by the testis of the 
rabbit has recently been emphasized (Ewing, Chubb \& Robaire, 1976). However, a specific binding protein for androgens (ABP) is believed to be a regulator of androgen levels within the lumen of the seminiferous tubules (Rommerts, Grootegoed \& van der Molen, 1976; Comhaire \& Vermeulen, 1976).

The role of ABP in the epididymis is less clear. Presumably the increase in the amount of radioactivity entering the lumen of the perfused epididymis from blood when rete testis fluid was added to the perfusate demonstrates an increase in luminal steroid binding sites due to ABP in this fluid (Hansson et al., 1975; Jegou, Dacheux, Terqui \& Garnier, 1976, 1977). There is direct evidence for the presence of ABP in epididymal fluid from the rabbit (Danzo, Cooper \& Orgebin-Crist, 1977) and ram (Jegou et al., 1976, 1977; Voglmayr et al., 1977), but not for the rat. However, after ligation of the vas deferens of the rat, French \& Ritzen (1973) demonstrated an accumulation of binding activity in the cauda epididymidis. In the present study, diluted epididymal fluid as perfusate augmented the uptake of radioactivity to a greater extent than did higher concentrations of albumin, suggesting that some binding component is present in the rat.

This study extends that of Back (1975) who obtained single samples of epididymal plasma $60 \mathrm{~min}$ after injection of $\left[{ }^{3} \mathrm{H}\right]$ testosterone, but found higher levels of radioactivity in the luminal fluid than blood. This could have been due to retention of steroid within the lumen and low levels in blood at that time after injection. Back (1975) also found that $73 \%$ of the radioactivity was associated with dihydrotestosterone, a metabolite that accumulates in the epididymis after systemic injection (Tindall, French \& Nayfeh, 1972). By contrast, in the present study, steroid was continuously presented to the epididymal epithelium during the period of infusion, and there was evidence for the presence of testosterone and dihydrotestosterone in the lumen in the presence of a non-specific binding protein. The proportion of dihydrotestosterone increased when a source of androgen-binding protein was present within the epididymal lumen.

The perfusion technique has demonstrated that the binding to luminal proteins is clearly of more importance in determining the entry of steroid than the length of the perfused segment or the perfusion rate. This binding would create a concentration gradient for the unbound forms of testosterone and dihydrotestosterone. These would diffuse into the lumen from the adjacent epithelial cells and similarly promote the movement of testosterone into the cells from blood. This increased transcellular flux of steroid, initiated by luminal proteins, would thus increase both the supply of substrate to, and the removal of product from, the epididymal $5 \alpha$-reductase. The extent of overall entry of radioactivity and the relative proportions of radiometabolites could therefore be influenced by the binding affinity of luminal proteins, and offer an explanation for the greater amounts of dihydrotestosterone found in the lumen of the cauda epididymidis of the rat (Vreeburg, 1975; Pujol, Bayard, Louvet \& Boulard, 1976).

Factors other than those discussed here (plasma binding, lipid solubility, presence of spermatozoa) could also contribute to the steady-state conditions existing in situ.

This work was supported by M.R.C. grant G976/020. Helpful discussions with Ms C. H. Yeung are acknowledged.

\section{References}

Back, D.J. (1975) The presence of metabolites of ${ }^{3} \mathrm{H}$ testosterone in the lumen of the cauda epididymidis of the rat. Steroids 25, 413-420.

Back, D.J. \& Shenton, J.C. (1975) A comparison of the composition of epididymal plasma from the cauda epididymidis of the rat, hamster and guinea-pig. Experientia 31, 464-465.

Bischoff, F. \& Stauffer, R.D. (1954) The dispersion of testosterone in aqueous bovine serum albumin solution. J. Am. Chem. Soc. 76, 1962-1965.
Cooper, T.G. \& Waites, G.M.H. (1979) Investigation by luminal perfusion of the transfer of compounds into the epididymis of the anaesthetized rat. J. Reprod. Fert. 56, 159-164.

Comhaire, F. H. \& Vermeulen, A. (1976) Testosterone concentration in the fluids of seminiferous tubules, the interstitium and the rete testis of the rat. $J$. Endocr. 70, 229-235.

Danzo, B.J., Cooper, T.G. \& Orgebin-Crist, M.C. (1977) Androgen binding protein (ABP) in fluid collected 
from the rete testis and cauda epididymidis of sexually mature and immature rabbits and observations on morphological changes in the epididymis following ligation of the ductuli efferentes. Biol. Reprod. 17, 64-77.

Edwards, E.M., Dacheux, J.L. \& Waites, G.M.H. (1976) Effects of $a$-chlorohydrin on the metabolism of testicular and epididymal spermatozoa of rams. $J$. Reprod. Fert. 48, 265-270.

Eik-Nes, K.B., Schellman, J.A., Lumry, R. \& Samuels, L.T. (1954) The binding of steroids to protein. 1 . Solubility determinations. J. biol. Chem. 206, 411419.

Ewing, L.L., Chubb, C.E. \& Robaire, B. (1976) Macromolecules, steroid binding and testosterone secretion by rabbit testes. Nature, Lond. 264, 84-85.

French, F.S. \& Ritzén, E.M. (1973) A high-affinity androgen-binding protein (ABP) in rat testis: evidence for its secretion into efferent duct fluid and absorption by epididymis. Endocrinology 93, 88-95.

Ganjam, V.K. \& Amann, R.P. (1976). Steroids in fluids and sperm entering and leaving the bovine epididymis, epididymal tissue, and accessory sex gland secretions. Endocrinology 99, 1618-1630.

Hamilton, D.W. (1971) Steroid function in the mammalian epididymis. J. Reprod. Fert., Suppl. 13, 8997.

Hammerstedt, R.H. \& Amann, R.P. (1976) Effects of physiological levels of exogenous steroids on metabolism of testicular, cauda epididymal and ejaculated bovine sperm. Biol. Reprod. 15, 678-685.

Hansson, V., Ritzén, E.M. \& French, F.S. (1975) Androgen transport and receptor mechanisms in testis and epididymis. In Handbook of Physiology, Section 7, Vol. 5, Male Reproductive System, pp. 173-202. Eds D. W. Hamilton \& R. O. Greep. American Physiology Society, Washington, D.C.

Jegou, B., Dacheux, J.L., Terqui, M. \& Garnier, D.H. (1976) Etude de la protéine de liaison de la $5 \alpha$ dihydrotestostérone (5-DHT) et de la testostérone dans le tractus génital mâle (bèlier). J. Physiol., Paris 72, 44-45A.

Jegou, B., Dacheux, J.L., Terqui, M. \& Garnier, D.H. (1977) Androgen binding protein (ABP) in the genital tract of the ram. J. Steroid Biochem. 8, 27A.

Johnson, A.L. \& Howards, S.S. (1976) Hyperosmolality in intraluminal fluids from hamster testis and epididymis: a micropuncture study. Science, N.Y. 195, 492-493.

Levine, N. \& Marsh, D.J. (1971) Micropuncture studies of the electrochemical aspects of fluid and electrolyte transport in individual seminiferous tubules, the epididymis and vas deferens. J. Physiol., Lond. 213, 557-570.
McKenna, J. \& Rippon, A.E. (1965) The extraction of plasma 3-hydroxy-17-oxo-steroid sulphates and the measurement of the constituent dehydroepiandrosterone sulphate and androsterone sulphate. Biochem. J. 95, 107-117.

Orgebin-Crist, M.C., Danzo, B.J. \& Davies, J. (1975) Endocrine control of the development and maintenance of sperm fertilizing ability in the epididymis. In Handbook of Physiology, Section 7, Volume 5, Male Reproductive System, pp. 319-338. Eds D. W. Hamilton \& R. O. Greep. American Physiology Society, Washington, D.C.

Pujol, A., Bayard, F., Louvet, J.P. \& Boulard, C. (1976) Testosterone and dihydrotestosterone concentrations in plasma, epididymal tissues, and seminal fluid of adult rats. Endocrinology 98, 111-113.

Rommerts, F.F.G., Grootegoed, J.A. \& van der Molen, H.J. (1976) Physiological role for androgen binding protein-steroid complex in testis? Steroids 28, 43-49.

Tindall, D.J., French, F.S. \& Nayfeh, S.N. (1972). Androgen uptake and binding in rat epididymal nuclei in vivo. Biophys. Biochem. Res. Commun. 49, 1391-1397.

Tuck, R.R., Setchell, B.P., Waites, G.M.H. \& Young, J.A. (1970) The composition of fluid collected by micropuncture and catheterisation from the seminiferous tubules and rete testis of rats. Pflügers Arch. ges. Physiol. 318, 225-243.

Voglmayr, J.K. (1975) Metabolic changes in spermatozoa during epididymal transit. In Handbook of Physiology, Section 7, Volume, 5, Male Reproductive System, pp. 437-451. Eds D. W. Hamilton \& R. O. Greep. American Physiology Society, Washington, D.C.

Voglmayr, J.K., Musto, N.A., Saksena, S.K., BrownWoodman, P.D.C., Marley, P.B. \& White, I.G. (1977) Characteristics of semen collected from the cauda epididymidis of conscious rams. J. Reprod. Fert. 49, 245-251.

Vreeburg, J.Th.M. (1975) Distribution of testosterone and $5 \alpha$-dihydrotesterone in rat epididymis and their concentrations in efferent duct fluid. $\dot{J}$. Endocr. 67, 203-210.

Waites, G.M.H. (1977) Fluid secretion. In The Testis, Vol. 4, pp. 91-123. Eds A. D. Johnson \& W. R. Gomes. Academic Press, New York.

Westphal, U. (1975) Steroid binding to serum proteins some open questions. In Normal and Abnormal Growth of the Prostate, pp. 616-631. Ed. M. Goland. C. C. Thomas, Springfield, Illinois.

Received 21 August 1978 